\title{
Prototype Sistem Monitoring Infus Berbasis IoT (Internet of Things)
}

\author{
Taufik Akbar ${ }^{1}$, Indra Gunawan ${ }^{2}$ \\ ${ }^{1,2}$ Program Studi Teknik Komputer, Universitas Hamzanwadi \\ email: aliakbar.akbar266@gmail.com ${ }^{1}$,artha_3119@yahoo.com²
}

(Received: 30 Oktober 2020 / Accepted: 15 Desember 2020 / Published Online: 20 Desember)

\begin{abstract}
Abstrak
Perkembangan ilmu kedokteran dan teknologi yang semakin canggih, demikian halnya perkembangan ilmu dan teknologi di bidang alat-alat kesehatan. Salah satu peralatan yang ada dan sering digunakan di rumah sakit salah satunya adalah infus. Saat ini pada dunia kesehatan, infus masih dikontrol secara manual. Karena dikontrol secara manual membutuhkan waktu jika perawat harus bolak balik keseluruh kamar pasien. Bukan hanya menghabiskan waktu, akan tetapi akan ada resiko jika terlambat menangani pasien yang infusnya sudah habis. Perlu permanfaatan teknologi untuk meminimalisir resiko didunia medis, salah satunya penerapan teknologi IoT. Penelitian ini bertujuan untuk membuat prototype monitoring infus berbasis IoT (Internet of Things). Metode yang digunakan untuk membangun alat ini adalah Waterfall. Pengujian alat ini menggunakan perangkat keras yang terdiri dari Load Cell dengan modul HX711 sebagai sensor berat, NodeMCU V3 sebagai prosesor, dan Web server Thingspeak sebagai interface dengan User. Hasil temuan kami menunjukkan bahwa alat yang dibuat terdapat eror sebesar 0,25 Gram, pengiriman data ke Server Thingspeak.com memerlukan koneksi yang bagus untuk hasil yang maksimal. Namun secara keseluruhan alat sudah berfungsi dengan baik walaupun ada beberapa kekurangan.
\end{abstract}

Kata Kunci: Infus, Internet of Things, Load Cell, NodeMCU V3.

\begin{abstract}
The development of increasingly sophisticated medical science and technology has an impact on the development of science and technology in the field of medical-devices. One of the existing equipment and is often used in hospitals, one of which is an IV. Currently in the world of health, infusion is still controlled manually. Because it takes time if the nurse has to go back and forth throughout the patient room. Not only is it time consuming, but there will be risks if it is too late to treat a patient whose infusion has run out. Technology needs to be used to minimize risks in the medical world, one of which is the application of IoT technology. This study aims to make it easier for nurses to control infusion conditions in real time using the concept of IoT ( the Internet of Things). The method used is the Waterfall method. This research uses hardware consisting of Load Cell with the HX711 module as a weight sensor, NodeMCU V3 as a processor, and Thingspeak Web server as the interface with the user. The results of the measurement of the tool made have an error of $0.25 \mathrm{Gram}$, sending data to the Thingspeak.com Server requires a good connection for maximum results.
\end{abstract}

Keywords: Infusion, Internet of Things, Load Cell, NodeMCU V3.

\section{PENDAHULUAN}

Infus merupakan salah satu kebutuhan teknis yang ada di dunia kesehatan. Intravena atau infus adalah sebuah metode pemberian obat yang dilakukan secara langsung melalui pembuluh darah. Terapi ini biasanya menjadi pilihan terbaik jika kondisi tubuh pasien sudah tidak memungkinkan minum obat secara oral (lewat mulut) (Swari, 2020). Infus merupakan salah satu obat yang paling berperan penting dalam rumah sakit, dan harus dikontrol penuh oleh seorang perawat. Infus harus dikontrol setiap saat, jika tidak maka akan mebahayakan pasien. Apabila sudah habis atau mendekati habis infus harus diganti dengan yang baru. Ada 
dua cara yang umum diterapkan untuk memasukkan cairan ke dalam pembuluh darah, yakni secara manual atau menggunakan pompa elektrik. Pemberian cairan harus tepat sesuai dengan kebutuhan pasien, terutama dari segi jenis dan dosis infus. Petugas medis dalam hal ini perawat wajib untuk melakukan kontrol terhadap infus yang sedang diberikan kepada pasien guna menjaga asupan obat (Verizarie, 2020).

Perkembangan ilmu kedokteran dan teknologi yang semakin canggih, demikian halnya perkembangan ilmu dan teknologi di bidang alat-alat kesehatan. Salah satu peralatan yang ada dan sering digunakan di rumah sakit salah satunya adalah infus. Alat infus ini digunakan untuk memberikan cairan ataupun obat kepada pasien sehingga memerlukan keakuratan agar tidak terjadi hal - hal yang tidak diinginkan (Muljodipo et al., 2015).

Saat ini pada dunia kesehatan, infus masih dikontrol secara manual. Karena dikontrol secara manual membutuhkan waktu jika perawat harus bolak balik keseluruh kamar pasien. Bukan hanya menghabiskan waktu, akan tetapi akan ada resiko jika terlambat menangani pasien yang infusnya sudah habis. Perlu permanfaatan teknologi untuk meminimalisir resiko didunia medis, salah satunya penerapan teknologi IoT (Internet of Things).

Dengan menggunakan konsep jaringan Internet of Things kita dapat membuat sebuah sistem yang bisa memantau infus pada pasien (Halifatullah et al., 2019). Di masa ini, penggunan internet merambah di segala aspek kehidupan manusia terutama dalam bidang pemantauan (Mulyati, 2018). Penelitian monitoring infus pernah dilakukan oleh Anwar dkk tahun 2018, pada penelitian tersebut menggunakan mikrokontroller Atmega16. Fitur penelitiannya ditambah menggunakan infrared dan photodiode, menggunakan sensor load cell. Hasil penelitian tersebut, alat dapat menghitung tetesan dengan error rata-rata $0,59 \%$ mendeteksi sisa cairan dengan error rata-rata $0,83 \%$ serta dapat mengirimkan data dengan waktu paling cepat 30 detik(Anwar \& Ibadillah, 2018) .

Teknologi IoT berkembang sebagai sebuah konsep yang bertujuan untuk memanfaatkan secara luas konektivitas jaringan komputer, khususnya internet, dalam implementasi aktivitas sehari-hari tanpa batas waktu ( Akbar, Gunawan, \& Utama, 2020). Internet of Things terdiri dari 2 kata kunci, Internet dan Things. Internet, memiliki arti interconnection-networking, dimana jaringan komputer yang terkoneksi satu dengan yang lain dengan menggunakan protokol TCP/IP (Transmission Control Protocol/ Internet Protocol) (Gunawan et al., 2020).

Menunjang perkembangan industry 4.0, penelitian ini membuat sebuah teknologi atau mesin yang bisa membantu dan mempermudah pekerjaan perawat dalam memonitoring infus pasien. Perawat hanya perlu membuka website monitoring thingspeak.com menggunakan komputer yang sudah terintegrasi dengan alatnya yang berada dikantor perawat. Thingspeak merupakan server yang dimanfaatkan beberapa produk yang berbasi IoT. ThingSpeak merupakan open source "Internet of Things" aplikasi dan API untuk menyimpan dan mengambil data dari hal-hal yang menggunakan HTTP melalui Internet atau melalui Local Area Network (Sari, 2016) . Pada dunia teknologi IoT tidak hanya dibutuhkan server akan tetapi dibutuhkan juga pendukung hardware (Perangkat Keras).

Salah satu perangkat keras yang mendukung teknologi monitoring yaitu mikrokontroller (Akbar, 2019). Pada penelitian ini mikrokontroller yang digunakan adalah NodeMCU. Mikrokontroller NodeMCU dapat mengirimkan dan menyimpan data ke server (Gunawan \& Fatimah, 2020). Node MCU diciptakan setelah ESP8266 muncul dipasaran yang di produksi pada saat sistem espressif mulai berkembang. ESP8266 merupakan Wireless Fidelity (WiFi) yang terintegrasi dengan core Tensilica Xtensa LX106 dan banyak diterapkan dalam aplikasi IoT (Ardian et al., 2017).

Penelitian ini bertujuan untuk membuat prototype monitoring infus berbasis IoT untuk memonitoring infus pasien secara real time dan juga bisa membantu para perawat mengurangi resiko kerja dalam mena ngani infus pasien. Alat ini berfungsi untuk 
memberikan informasi kondisi infus yang terdapat di ruang pasien dan Tujuan penelitian ini adalah

\section{METODE}

Metode Waterfall adalah suatu proses pengembangan perangkat lunak berurutan, di mana kemajuan dipandang sebagai terus mengalir ke bawah (seperti air terjun) melewati fasefase perencanaan, pemodelan, implementasi (konstruksi), dan pengujian. Dalam pengembangannya metode waterfall memiliki beberapa tahapan yang runtut: requirement (analisis kebutuhan), design sistem (system design), Coding \& Testing, Penerapan Program, pemeliharaan (Morris, 1942).

Proses pengembangan yang sangat terstruktur ini membuat potensi kerugian akibat kesalahan pada proses sebelumnya sangat besar dan acap kali mahal karena membengkaknya biaya pengembangan ulang (Tristianto, 2018). Metode Waterfall bias menghasilkan penelitian benar dan terperinci dengan baik (Sulenggono, 2017).

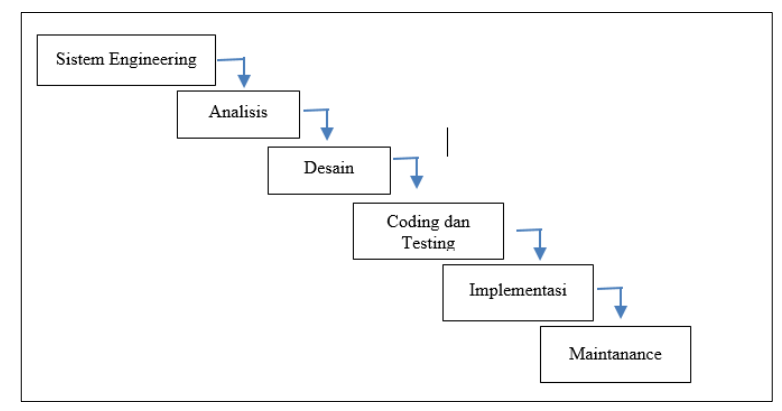

Gambar 1. Metode Waterfall menurut Presman (Morris, 1942).

Berdasarkan gambar 1 di atas, ada 6 tahapan yang pertama System / Information Engineering and Modeling, Permodelan ini diawali dengan mencari kebutuhan dari seluruh komponen Prototype. Mulai dari pemilihan Hardware dan Software yang digunakan . yang kedua Software Requirements Analysis, Proses pencarian kebutuhan diintensifkan dan difokuskan pada software. Yang ketiga Design, Proses ini digunakan untuk mengubah kebutuhan-kebutuhan diatas menjadi representasi ke dalam bentuk "blueprint" software sebelum coding dimulai. Desain harus dapat mengimplementasikan kebutuhan yang telah disebutkan pada tahap sebelumnya. Seperti 2 aktivitas sebelumnya, maka proses ini juga harus didokumentasikan sebagai konfigurasi dari software.

Yang keempat Coding. Untuk dapat dimengerti oleh mesin, dalam hal ini adalah komputer, maka desain tadi harus diubah bentuknya menjadi bentuk yang dapat dimengerti oleh mesin, yaitu ke dalam bahasa pemrograman melalui proses coding. Tahap ini merupakan implementasi dari tahap design yang secara teknis nantinya dikerjakan oleh programmer. Yang kelima Testing / Verification. Sesuatu yang dibuat haruslah diujicobakan. Demikian juga dengan software. Semua fungsifungsi software harus diujicobakan, agar software bebas dari error, dan hasilnya harus benar- benar sesuai dengan kebutuhan yang sudah didefinisikan sebelumnya.

Tahapan yang terakhir adalah maintenance, yakni Pemeliharaan suatu software diperlukan, termasuk di dalamnya adalah pengembangan, karena software yang dibuat tidak selamanya hanya seperti itu. Ketika dijalankan mungkin saja masih ada errors kecil yang tidak ditemukan sebelumnya, atau ada penambahan fitur-fitur yang belum ada pada software tersebut. Pengembangan diperlukan ketika adanya perubahan dari eksternal perusahaan seperti ketika ada pergantian sistem operasi, atau perangkat lainnya 
Dari kenyataan yang terjadi sangat jarang model Waterfall dapat dilakukan sesuai alurnya (Hidayat et al., 2017) yakni: 1) Perubahan spesifikasi perangkat lunak terjadi di tengah alur pengembangan, 2) Sangat sulit bagi pelanggan untuk mendefinisikan semua spesifikasi diawal alur pengembangan. Pelanggan seringkali btuh contoh (prototype) untuk menjabarkan spesifikasi kebutuhan sistem lebih lanjut, 3) Pelanggan tidak mungkin bersabar mengakomodasikan perubahan yang diperlukan di akhir alur pengembangan.

\section{HASIL DAN PEMBAHASAN}

Hasil

Sistem monitoring infus yang sudah dibangun ini berupa sistem yang memonitor keadaan jumlah cairan infus pasien secara real time dan dapat diakses melalui WEB atau Smartphone. Sistem ini dibangun menggunakan hardware berupa sensor load cell, nodemcu, dan software berupa aplikasi Blynk. Adapun Alur rancangan sistem dapat dilihat pada gambar 2 yang terdiri dari: 1) Inpus sebagai inputan (yang diukur), 2) Sensor Load Cell akan menerina nilai (berat) dari infus berupa signal Analog, signal analog dikirim ke kaki/pin ADC NodeMCU, 3) NodeMCU menerima signal Analog dari Sensor kemudain diproses dan dikirim ke Esp8266 untuk dijadikan data server, dan 4) Web server akan memberikan informasi berupa tampilan kondisi dari infu di komptuer.

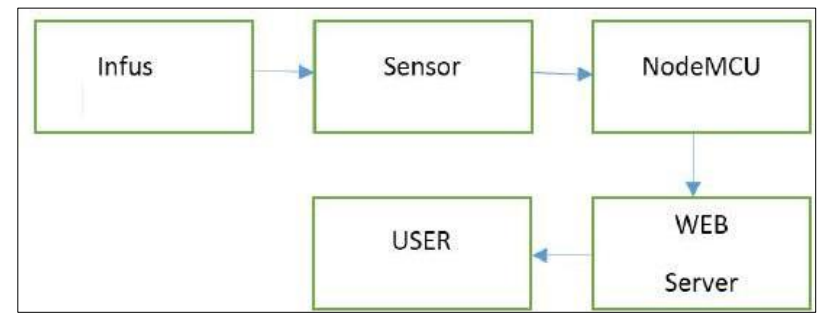

\section{Sensor Loadcell}

Adapun rangkain sensor Op-Amp loadcell ,menggunakan modul HX711. Berdasarkan Avia Semiconductor yang dipatenkan teknologi, HX711 adalah konverter analog ke digital 24-bit (ADC) presisi yang dirancang untuk penimbangan aplikasi skala dan kontrol industri untuk antarmuka langsung dengan bridge sensor.

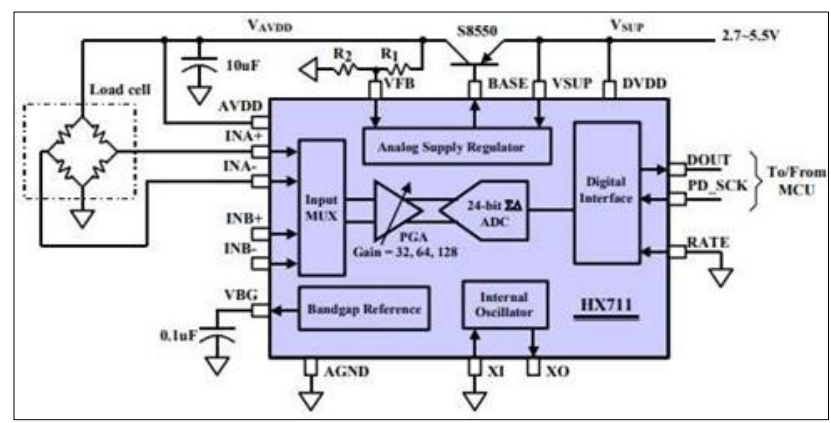

Gambar 3 : Rangkaian HX711

Pada gambar 3, dijelaskan bahwa Multiplexer input memilih Saluran A atau input diferensial B ke derau rendah amplifier yang dapat diprogram (PGA). Saluran A dapat diprogram dengan gain 128 atau 64, sesuai dengan input diferensial skala penuh tegangan masing-masing $\pm 20 \mathrm{mV}$ atau $\pm 40 \mathrm{mV}$ catu $5 \mathrm{~V}$ terhubung ke daya analog AVDD pin pasokan. Saluran B memiliki perolehan tetap 32. Regulator catu daya Onchip menghilangkan kebutuhan untuk regulator pasokan eksternal untuk menyediakan analog kekuatan untuk ADC dan sensor. Input jam adalah fleksibel. Itu bisa dari sumber jam eksternal, a kristal, atau 
osilator on-chip yang tidak memerlukan komponen eksternal. Sirkuit reset-daya power-chip menyederhanakan antarmuka digital inisialisasi.

\section{Pengujian Koneksi Internet NodeMCUV3}

Pengujian ini dilakukan untuk memastikan bahwa perangkat yang digunakan, koneksi internetnya stabil. Berdarkan hasil diatas bahwa perangkat NodeMCU sudah bisa digunakan karena sudah terkoneksi dengan Wifi yang ada (lihat gambar 4).

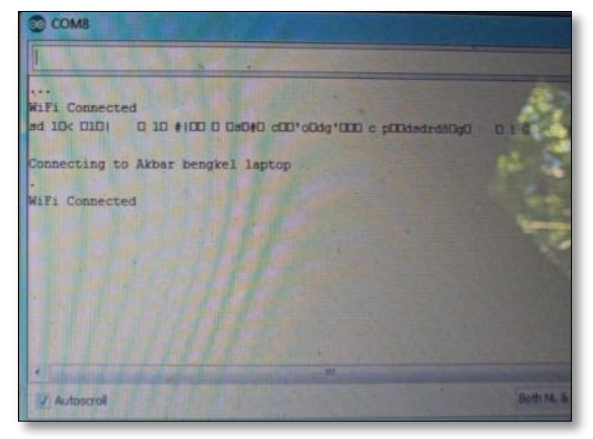

Gambar 4. Hasil Pengujian Koneksi nodeMCU

\section{Perancangan Prototype Perangkat Keras/Hardware}

Adapun tahapan dalam perancangan hardware yang dilakukan desain gantungan infus, dan instalasi perangkat.

\section{Perancangan Desain Gantungan Infus.}

Pada penelitian ini dibutuhkan desain yang sesuai dengan kondisi infus yang sebenarnya, pada gambar 5 terdapat 3 bagian yang penting yaitu yang pertama posisi dari sensor load cell, yang kedua posisi tiang penyangga dan yang ketiga posisi gantungan infus. Gantungan infus diseseuaikan dengan model sensor load cell. Adapun hasil real terapan dari desain yang sudah dibuat ada di gambar 6 dan sudah terpasang infus dengan beban berat $500 \mathrm{~mL}$.

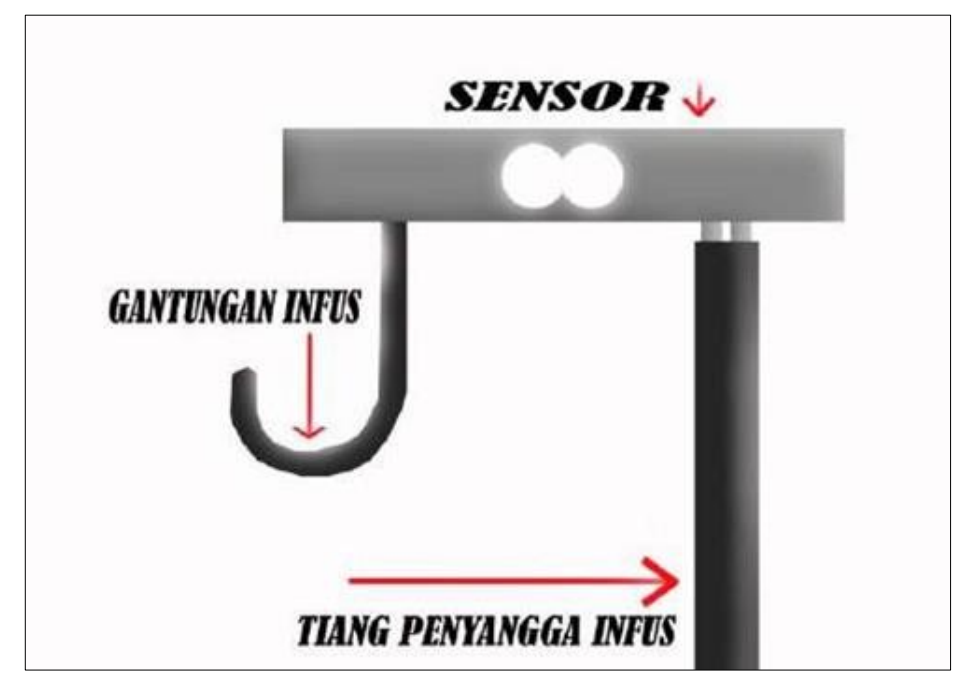

Gambar 5. Desain gantungan Infus 


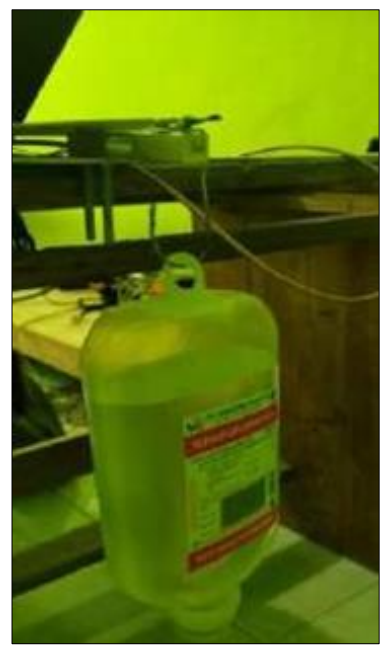

Gambar 6. Hasil Perancangan gantungan Infus.

\section{Instalasi Perangkat.}

Adapun skema yang digunakan Seperti gambar dibawah ini. Pada skema dibawah terdapat 3 bagian penting yaitu yang pertama NodeMCU sebagai prosesor, yang kedua rangkaian HX711 sebagai translator nilai analog menjadi digital dan yang terakhir sensor Load Cell sebagai sensor berat yang nampak pada gambar 7. Selanjutnya, berdasarkan skema sensor tersebut dilakukan instlasi perangkat keras yang terlihat apda gambar 8 .

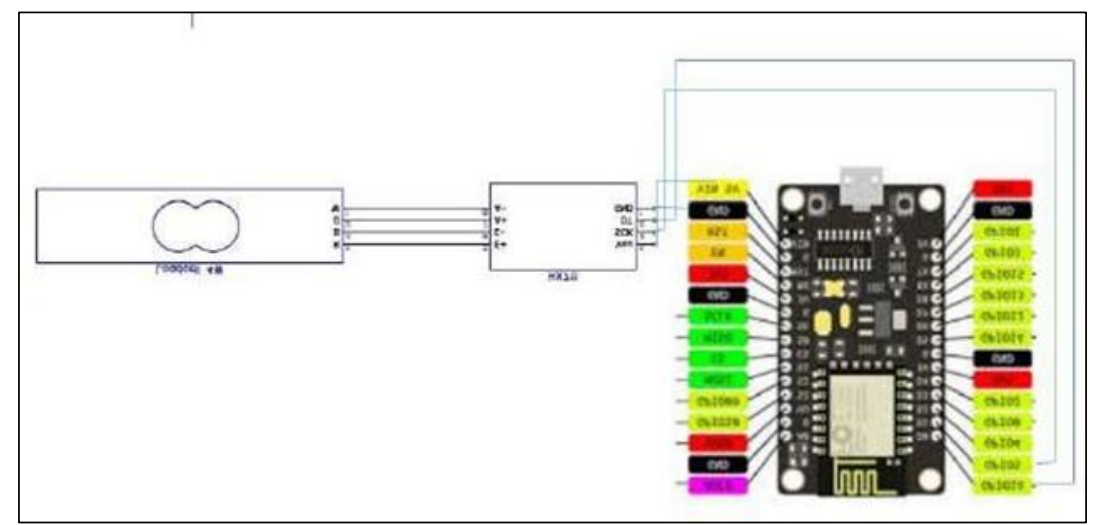

Gambar 7. Skema Sensor dan NodeMCU.

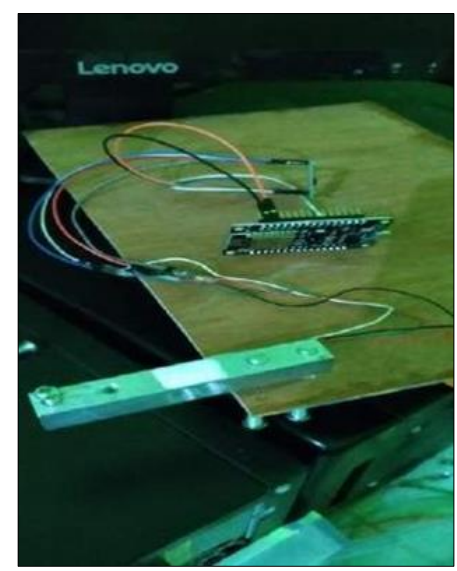

Gambar 8. Hasil Instalasi Perangkat Keras. 


\section{Tampilan Grafik Pada Monitor Komputer}

Pada Prototype ini kita menggunakan WEB server Thingspeak.com . Pada Web server ini ada bebrapa fitur yang bisa kita gunakan, salah satunya monitoring. Pada gambar 9 dan 10 adalah hasil tampilan prototype ketika infus kosong dan terisi dan terdapat fitur LED Indikator dan pembacaan hasil sensor. Nilai Error pada hasil yang dibaca sensor bernilai 0,25 Gram, yang seharusnya adalah bernilai 0. Adapun fitur tambahan yang diberikan berupa indikator lampu yang berwarna merah yang ditambhakn dengan speaker Buzzer. Hal ini mengingatkan jika klien atau admin sedang tidak dalam posisi stanby.

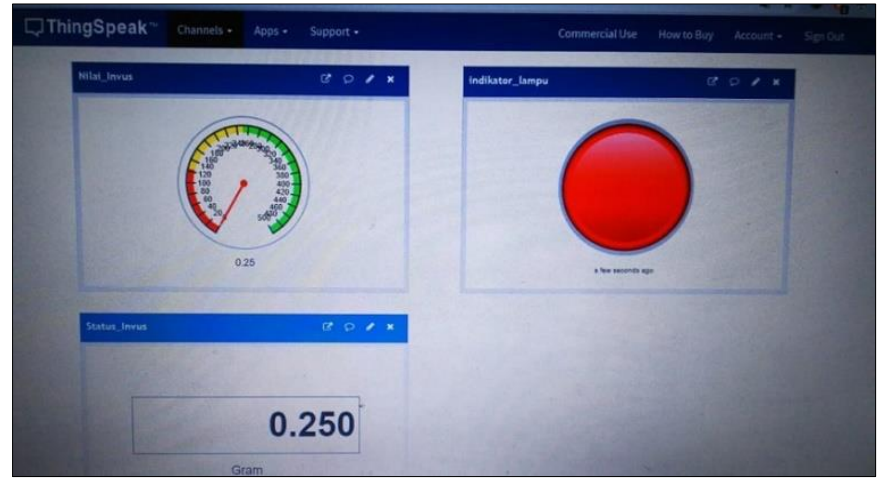

Gambar 9. Tampilan Grafik pada WEB saat Kondisi Infus Kosong.

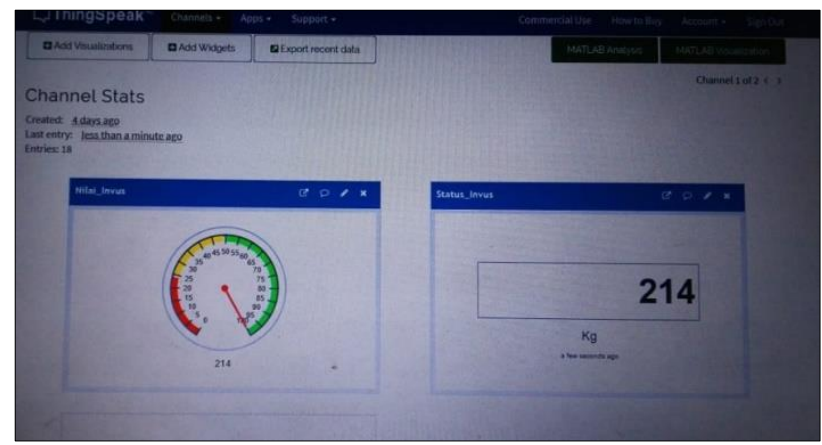

Gambar 10. Hasil Grafik pada Web saat Kondisi Infus Full.

\section{Pembahasan}

Sebelum melakukan terapan dari prototype, peneliti melakukan pengamatan dari beberapa refrensi (artikel atau jurnal dan beberapa situs Web) yang berkatian dengan penelitian ini. Pada penelitian yang dilakukan (Anwar \& Ibadillah, 2018) menggunakan mikrokontroller Atmega16 yang dimana mikrokontroller ini menggunakan Bahasa C, modul ESP8266 dan downloader berupa ISP. Pada Penelitian ini akan membutuhkan daya yang banyak karena banyak module yang digunakan. Hal itu yang menjadikan peneliti pada artikel ini untuk menggunakan NodeMCU yang sudah include dengan Esp8266 sehingga menggunakan daya yang rendah.

Pada hasil temuan oleh Yudhana \& Putra (2018) hanya menggunakan photodiode sebagai sensor sehingga hanya akan membaca tetesan infus saja. Indikator atau alarm akan menyala jika sudah tidak ada tetesan lagi artinya infus dalam kondisi kosong. Hal itu akan mebahayakan pasien, karena akan kemungkinan terjadi darah pada pasien tersedot infus. Karena beberapa kekurangan pada penelitian ini yang menjadi tambahan fitur pada prototype artikel ini, pada prototype ini penulis menggunakan simbol tombol merah jika infus sudah mau habis, bukan lagi menunggu infus habis.

Pada penelitian ini perangakat keras yang pertama diselesaikan yaitu coding untuk mikrokontroller NodeMCU, yang berfungsi sebagai Prosesor utama pada prototype ini. 
Setelah itu dilakukan beberapa tahapan pengujian yang pertama pengujian koneksi seperti gambar 4. Selanjutnya pengujian sensor Load Cell dengan membaca sinyal yang dihasilkan sensor, sinyalnya berupa analog. yang terakhir pengujian koneksi pada WEB server(Thingspeak.com).

Setelah melakukan perakitan beberapa komponen inti pada prototype, ada bagian yang paling sulit dilakukan, yaitu pada perakitan kontrol sensor. Kontrol Sensor ini sangat sensitif terhadap gerakan, setiap gerakan akan terhitung nilai dari ADC (Analog) yang akan di konversi menjadi digital. Akan ada gerakan dari infus yang terhitung dan terbaca pada WEB Server dan nilai tersebut tidak akan dibaca menjadi nilai error.

\section{SIMPULAN}

Setelah diterapkannya monitoring infus berbasis IoT, kita dapat menyimpulkan bahwa sensor Load Cell berfungsi dengan baik, dengan mendapatkan nilai error saat kondisi infus dalam keadaan kosong, dengan nilai 0,25 Gram. Pada Pengiriman data ke Server Thingspeak.com memerlukan koneksi yang bagus untuk hasil yang maksimal dan Secara keseluruhan alat sudah berfungsi dengan baik walaupun ada beberapa kekurangan.

\section{REFERENSI}

Akbar, T., Gunawan, I., \& Utama, S. (2020). Prototype System of Temperature and Humadity Automatic in Oyster Mushroom Cultivation using Arduino Uno. Journal of Physics: Conference Series, 1539 (1), 1-6. $\quad$ https://doi.org/10.1088/17426596/1539/1/012036

Akbar, T., Suweken, G., Indrawan, G., \& Aryanto, K. Y. E. (2019). Kotak-Kontak Pintar Pada Rumah Cerdas Berbasis Teknologi Internet of Things. Jurnal Pendidikan Teknologi Dan Kejuruan, 16 (2), 278. https://doi.org/10.23887/jptkundiksha.v16i2.18937

Anwar, H. N., \& Ibadillah, A. F. (2018). Alat Pemantau Kondisi Infus Dengan Internet Of Things (IoT) Berbasis Mikrokontroler ATmega16. Jurnal Teknik Elektro dan Komputer TRIAC, 5(1), 1-5. https://doi.org/10.21107/triac.v5i1.3581

Ardian, H., Triyanto, D., \& Rismawan, T. (2017). Sistem Kendali Lampu Dan Steker Terintegrasi Menggunakan Mikrokontroler Berbasis Web Service 1,2,3. Jurnal Coding Sistem Komputer Untan, 05(3), 40-47.

Gunawan, G., \& Fatimah, T. (2020). Implementasi Sistem Pengaturan Suhu Ruang Server Menggunakan Sensor DHT11 dan Sensor PIR Berbasis Mikrokontroler. Edumatic: Jurnal Pendidikan Informatika, 4(1), 101-110. https://doi.org/10.29408/edumatic.v4i1.2165

Gunawan, I., Akbar, T., \& Giyandhi Ilham, M. (2020). Prototipe Penerapan Internet Of Things (Iot) Pada Monitoring Level Air Tandon Menggunakan Nodemcu Esp8266 Dan Blynk. Infotek: Jurnal Informatika Dan Teknologi, 3(1), 1-7. https://doi.org/10.29408/jit.v3i1.1789

Halifatullah, I., Sulaksono, D. H., \& Tukadi, T. (2019). Rancang Bangun Sistem Monitoring Dan Kontrol Infus Dengan Penerapan Internet Of Things (Iot) Berbasis Android. positif: Jurnal Sistem Dan Teknologi Informasi, 5(2), 81-88. https://doi.org/10.31961/positif.v5i2.740

Hidayat, R., Marlina, S., \& Utami, L. D. (2017). Perancangan Sistem Informasi Penjualan Barang Handmade Berbasis Website Dengan Metode Waterfall. Simnasiptek 2017, 1(1), 175-183.

Morris, J. E. (1942). Waterfalls. Notes and Queries, 183(10), 297-b.

Muljodipo, N., Sompie, S. R., \& Robot, R. F. (2015). Rancang Bangun Otomatis Sistem Infus Pasien. Jurnal Teknik Elektro dan Komputer, 4(4), 12-22. 
https://doi.org/10.35793/jtek.4.4.2015.8567

Mluyati, S., \& Sadi, S. (2019). Internet Of Things (IoT) Pada Prototipe Pendeteksi Kebocoran Gas Berbasis MQ-2 Dan SIM800L. Jurnal Teknik, 7(2), 64-72.

Sari, U. P. (2016). Kapita Selekta. Retrieved from http://edocs.ilkom.unsri.ac.id/474/1/09011181320003_Ulan Purnama Sari_TASK2.pdf

Sulenggono, R. (2017). Penerapan Sistem Informasi Smart Classroom Berbasis Internet Of Things Dengan Raspberry PI Di Jurusan Teknik Informatika Universitas Negeri Surabaya. IT-Edu : Jurnal Information Technology and Education, 2(2), 256-262.

Swari, R. C. (2020). Serba-serbi Infus: Mulai dari Prosedur Pemasangan Hingga Risiko Efek Sampingnya. Https://Hellosehat.Com. https://hellosehat.com/hidup-sehat/faktaunik/penyebab-tangan-di-infus/\#gref

Tristianto, C. (2018). Penggunaan metode waterfall untuk pengembangan sistem monitoring dan evaluasi pembangunan pedesaan. Jurnal Teknologi Informasi ESIT, 12(1), 8-22.

Verizarie, R. (2020). Infus: Fungsi, Prosedur Pemasangan, Efek Samping. Https://Doktersehat.Com/. https://doktersehat.com/infus/

Yudhana, A., \& Putra, M. D. D. (2018). Rancang Bangun Sistem Pemantauan Infus Berbasis Android. Transmisi, 20(2), 91-95. 